\title{
Juridical Economic Policy in the Doctrine of Ecological Order
}

\author{
Stepanenko R.F. \\ Theory and History of State and Law Department \\ University of management "TISBI" \\ Kazan, Russia \\ stepanenkorf@yandex.ru \\ Alamova S.M. \\ Business Law Department \\ University of management "TISBI" \\ Kazan, Russia \\ sm-alamova@mail.ru
}

\author{
Yun L.V. \\ Theory and History of State and Law Department \\ University of management "TISBI" \\ Kazan, Russia \\ yun.lara@yandex.ru \\ Lyagin K.A. \\ Theory and History of State and Law Department \\ University of management "TISBI" \\ Kazan, Russia \\ lyagin.kirill@yandex.ru
}

\begin{abstract}
The article discusses the issues of juridical economic policy in the concept of the ecological order, built and developed by representatives of foreign natural humanitarian interdisciplinary scientific fields at the turn of the XIX - XX centuries. Juridical economic policy should establish fundamental and priority principles for building a state based on law. The concept of the ecological order states the most important problems for scientists concerning mankind survival in terms of natural resources exhaustion. Nowadays, human activity aimed at nature state deterioration becomes the subject of study for social ecology. The latter pays attention to interaction between human society and natural environment. Juridical economic policy should become the basis for an even and equitable distribution of the natural resources of all mankind in general and ecological order preservation. The article has practical importance for specialists in the field of jurisprudence and in the field of scientific research for social and humanitarian studies.
\end{abstract}

Keywords-ecological order; juridical economic policy; natural resources; social-humanitarian studies.

\section{INTRODUCTION}

The concept of ecological order, built and developed by representatives of foreign natural - humanitarian interdisciplinary scientific fields at the turn of the XIX - XX centuries, set global problems of mankind survival in terms of natural resources exhaustion, environment pollution, the risk of technological disasters, fauna decrease, quick increase of industrial objects amount, which damage life quality of society in general.

\section{LITERATURE REVIEW}

One of the first representatives of ecological order concept E. Haeckel, introduced into scientific circulation of natural-scientific knowledge "ecology" notion, which was then used by scientists of foreign sociological school in terms of crisis phenomena of industrial society study, in which the values of a person's responsibility for the life of the future generations were violated.

Anthropogenic factor (human activity) of nature state worsening, conditioned by the desire to use natural resources with maximal benefit for pragmatic aims of society (groups, individuals) and which damages integrity of ecosystem, becomes the subject of study for social ecology. The latter pays great attention to studying nature development laws inconsistence with social technological evolution, in which a person's influence, and first of all, migrant's influence on the quality of his life, is studied in the methodology of interdisciplinarity.

Demographic and migration problems study by the example of American contingent of the mentioned period, led R. E. Park and those, who had identical ideas (A. Antonovski, A. Burgess, G. Gurunt, V. Manchini, E. Stonequist and others) to the conclusion that migrants' marginality, detachment and unadjustment to socialnormative sphere (marginality) led to crisis in biopsychological and social cultural state of a migrant, who for a long time (or forever- E. Stonequist) presented "cultural hybrid", with typical for him disorganized character, anxiety, tension and frustration.

Several decades later, Soviet marginalism (N. Temkin, V. Prol, E. Starikov, P. Chervinskiy) being based on ideologized Marxian understanding of social order, where the base is economics and the law is superstructure, extrapolates the notion "marginal person" into the concept of economic order with its interpretation as inadequate member of Soviet society, in negative meaning. At the same time, attention is not paid to ecology as the sphere, which has difficulties in connection with human activity.

\section{RESEARCH METHODOLOGY}

Methodological basis of the research are general, scientific and individual scientific methods of cognition and 
[3]. Romashov R., Timofeeva E.A., Tonkov E.N. Prison industry: economy, law and information and communication technologies Advances in Intelligent Systems and Computing. 2019, vol. 726, pp. 563-572.

[4]. Khazieva, N., Khaziev, A., Klyushina, E., Stepanenko, G., \& Stepanenko, R. «Friends" and «Foes» in the Social Space of the Tatar Ethnic Group. Journal of History Culture and Art Research. 2017, 6(4), pp. 1237-1244.

\section{RESULTS}

In terms of studying the problems of ecological order in economic system of communities, such notion as marginality becomes important. Multidisciplinary notion "marginality" is reflected in regulative sphere of international law. In Resolution of the General Assembly of UNO 14.12.1990 marginality means great number of "risk groups" of migrants, people with antisocial behavior, which government, State Justice Institutes, law-enforcement systems, mass media and scientists, who create the programs and the politics of law violation prevention, should pay attention to ${ }^{1}$. The influence of migration, which is characterized as a marginal phenomenon (alienated, conterminous), is urgent nowadays during ecological order problem study, which is closely connected and depends on economic politics, provided by the states. It is proved by problems both at state and international levels.

\section{DISCUSSION}

Paradigm of constitutionalism provides economic ideology of state inventory with the help of which imposed and not safe values of consumer's life style, culture, education, medicine and other spheres of life commercialization should be recultured.

Juridical economic politics should be open and clear for the citizen of Russia. It shouldn't have discriminative character for most part of Russian population, should be the base for safe and just natural resources distribution for the benefit of a human being and ecological order preservation in order to continue generations and develop civilization.

\section{CONCLUSION}

Undoubtedly, marginality phenomenon, being interesting for humanitarian Russian science (more than 60 dissertations, the object of which is marginality) couldn't but be interesting for native juridical science. So the research workers of general juridical theory of marginality from general scientific humanistic positions of a person's constitutional right and freedoms defense, including "marginal person" in his dualistic (native and foreign) meaning, substantiate the necessity to form juridical ethnopolitics and juridical economic politics, which have serious preventive meaning for law and then ecological order in modern state structure setting.

\section{References}

[1]. Resolution of the General Assembly of UNO 14.12. 1990 № 45/112: URL: http//base. garant.ru/12123837.

[2]. Park R.T. Human migration the marginal man. American Journal of Sociology. 1928, 6, 138.

\footnotetext{
${ }^{1}$ See.: Resolution of the General Assembly of UNO 14.12. 1990 № 45/112. URL: http//base. garant.ru/12123837.
}

[5]. Ibragimov G.I., Ibragimova E.M., Bakulina L.T. The state and prospects of problem-based learning development in higher education. IEJME: Mathematics Education. 2016, vol. 11, 4, pp. 881-889.

[6]. Bakulina L.T. "The roman spirit" of the code of napoleon. Mediterranean Journal of Social Sciences. 2014, vol. 5, 24, pp. 477479.

[7]. Dzhansarayeva R.Ye., Romashov R.A., Baisalov A., Akbolatova M.E. Theory of legal responsability. Bulletin d'EUROTALENT-FIDJIP. 2014, 3, pp. 88-90.

[8]. Lipinsky D., Bolgova V., Musatkina A. Problems of legal education internationalization. Espacios. 2019, vol. 40, 9, 28.

[9]. Malashenko Y., Sokolov I., Romanovskaya V. Role of monooxygenase reaction during assimilation of non-growth substrates by methanotrophs. Journal of Molecular Catalysis B: Enzymatic. 2000, vol. 10, 1-3, pp. 305-312.

[10]. Alexsandr S. Kuznetsov. Russian Professor's meeting. Russian Journal of Physical Education and Sport. 2019, 14(1), pp. 17-22. DOI: DOI 10.14526/2070-4798-2019-14-1-18-24

[11]. Rybakov O.Yu., Tikhonova S.V. Doctrine of natural law and philosophy of transhumanism: the possibility of communication. Lex Russica. 2014, vol. 96, 2, pp. 143-152. 